\title{
THE HEALTH OF THE CHILDREN - RESIDENIS OF RADIATION-CONTAMINATED IERRITORIES, BORN AFTER THE CHORNOBYL DISASTER
}

\author{
Yaroshenko Zh.S.
}

\section{ЗДОРОВ’Я ДІТЕЙ - МЕШКАНЦІВ РАДІАЦИЙНО-ЗАБРУДНЕНИХ ТЕРИТОРІЙ, НАРОДЖЕНИХ ПІСЛЯ ЧОРНОБИЛЬСЬКОÏ КАТАСТРОФИ}

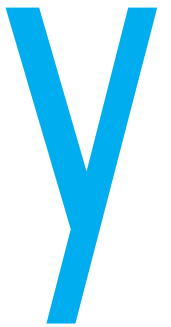

ЯРОШЕНКО Ж.С.

ДУ «Національний науковий центр радіаційної медицини НАМН України», м. Київ, Україна

\section{Ключові слова: нащадки першого покоління, радіаційно-забруднена територія, непухлинні захворювання час народження після аварії.}

1986 році через аварію на Чорнобильській атомній електростанції (ЧАЕС) радіаційного забруднення зазнали 12 областей України 3 населенням 2,6 млн. людей у 2207 поселеннях. За законом України, «зона гарантованого добровільного відселення це територія 3 щільністю забруднення ґрунту понад доаварійний рівень ізотопами цезію 5,0-15,0 Ki/KM² або стронцію від 0,15 Ki/кM ${ }^{2}$ до 3,0 Ki/Kм², або плутонію від 0,01 до 0,1 Ki/км², де розрахункова ефективна еквівалентна доза опромінення людини 3 урахуванням коефіцієнтів міграції радіонуклідів у рослини та інших факторів може перевищити 1,0 мЗв
(0,1 бер) на рік понад дозу, яку вона одержувала у доаварійний період» [1].

За останні роки зменшилися рівні радіоактивного забруднення у багатьох населених пунктах гарантованого добровільного переселення (зона 3), проте залишаються території України, які за дозовим критерієм визнаються радіоактивно-забрудненими [2].

Епідеміологічні дослідження стану здоров'я осіб, які постраждали через аварію на ЧAEC, показали, що за 30 років після аварії (1986-2016) зросла соматична патологія серед потерпілих. Одним 3 наслідків Чорнобильської катастрофи є збільшення непухлинної захворюваності дорос-
ЗДОРОВЬЕ ДЕТЕЙ - ЖИТЕЛЕЙ РАДИАЦИОННОЗАГРЯЗНЕННЫХ ТЕРРИТОРИЙ, РОДИВШИХСЯ ПОСЛЕ ЧЕРНОБЫЛЬСКОЙ КАТАСТРОФЫ

Ярошенко Ж.С.

ГУ «Национальный научный центр радиационной медицины НАМН Украины», Г. Киев

Цель исследования: изучение структуры неопухолевых заболеваний потомков первого поколения, жителей радиационно-загрязненных территорий, 1987-1999 годов рождения.

Материалы и методы. Источником информации послужила база данных Государственного регистра Украины (ГРУ) пострадавших в результате аварии на ЧАЭС от ионизирующего излучения. Базовая когорта составила 15174 потомка из них 7681 мужчина, 7493 женщины. В зависимости от даты рождения после аварии были сформированы четыре гуппы исследования возрастом 0-3 года: I - 01.03.1987-28.02.1990 годов рождения, II - 01.03.1990-28.02.1993, III - 01.03.1993-28.02.1996, IV - 01.03.199628.02.1999. Период эпидемиологического исследования составил 18 лет от даты рождения потомков. Изучалась структура неопухолевых заболеваний. Расчеты показателя проводились с использованием пакета программ «Microsoft Office Excel-2013».

Результаты исследований. Впервые по результатам проведенного эпидемиологического исследования показаны особенности изменения в структуре неопухолевых заболеваний у потомков первого поколения в зависимости от даты рождения после аварии. Основную роль в изменении структуры сыграли болезни органов дыхания, пищеварения и эндокринной системы, которые составили большую часть всех заболеваний - 75\%. При этом у детей мужского пола преобладают заболевания органов дыхания, женского - эндокринная патология и болезни органов пищеварения. Выявлена зависимость развития неопухолевых заболеваний от времени аварии на ЧАЭС и даты рождения потомков. Доля болезней органов дыхания, расстройств психики и поведения, а также врожденных аномалий и пороков развития увеличивается в 2 раза у детей, рожденных через 10-12 лет после аварии, в сравнении с детьми, родившимися в первые годы после аварии.

В то же время наблюдается уменьшение удельного веса болезней эндокринной системы и пищеварения в зависимости от отдаленности рождения детей после Чернобыльской катастрофы.

Выводы. Выявлена зависимость развития неопухолевых заболеваний за исследованными классами заболеваний у потомков первого поколения жителей радиационно-загрязненных территорий от времени рождения после аварии на ЧАЭС.

Полученные результаты эпидемиологического анализа являются предварительными и нуждаются в дальнейших углубленных исследованиях.

Ключевые слова: потомки первого поколения, радиационно-загрязненная территория, неопухолевые заболевания, дата рождения после аварии.

() Ярошенко Ж.С. СТАТТЯ, 2019. 
лих та дітей, які народилися після аварії [2, 3]. Особливою проблемою $є$ стан здоров'я осіб дитячого і підліткового віку, які народилися та мешкають на радіаційно-забруднених територіях (РЗТ) України. Наукові дослідження за останні 30 років свідчать про збільшення непухлинної захворюваності порівняно 3 популяційними показниками та у динаміці років дослідження $[4,5]$.

Особливо актуальним нині $€$ вивчення стану здоров'я нащадків першого покоління, народжених після аварії від батьків, які зазнали внутрішнього і зовнішнього радіаційного опромінення та мешкають на РЗТ $[6,7]$. Стан здоров'я дітей характеризується зниженням імунітету, погір- шенням психосоматичного здоров'я, мутаціями у геномі, що призводять до мультифакторної патології організму, що розвивається [8]. Постає питання вивчення зміни стану здоров'я нащадків першого покоління, мешканців радіаційно-забруднених територій, народжених після аварії на ЧАЕС, з досягненням ними 18річчя для розробки цілеспрямованих заходів та організації медичної допомоги на первинній ланці для збереження та покращання здоров'я, їхньої працездатності у дорослому віці.

Мета дослідження: вивчення структури непухлинних захворювань у дітей - мешканців РЗТ 1987-1999 років народження 3 досягненням ними 18-річчя.

Матеріал та методи дослідження. Джерелом інформації для проведення епідеміологічного дослідження стану здоров'я нащадків першого покоління слугувала база даних Державного реєстру України (ДРУ) осіб, які постраждали через Чорнобильську катастрофу. Чисельність нащадків першого покоління, народжених мешканцями РЗТ з 01.03.1987 р. по 28.02.1999 р., по Україні становить 99732

Таблиця 1

Розподіл нащадків першого покоління, народжених мешканцями радіаційно-забруднених територій України, залежно від років їх народження та статі

\begin{tabular}{|l|c|c|c|}
\hline \multirow{2}{*}{$\begin{array}{c}\text { Досліджувані групи нащадків першого } \\
\text { покоління, дати народження }\end{array}$} & \multicolumn{3}{|c|}{ Чисельність нащадків } \\
\cline { 2 - 4 } & чоловічої & жіночої & разом \\
\hline Перша, 01.03.1987-28.02.1990 & 2358 & 2238 & 4596 \\
\hline Друга, 01.03.1990-28.02.1993 & 2057 & 2020 & 4077 \\
\hline Третя, 01.03.1993-29.02.1996 & 2116 & 2148 & 4264 \\
\hline Четверта, 01.03.1996-28.02.1998 & 1150 & 1087 & 2237 \\
\hline
\end{tabular}

Сумарні (зовнішні та внутрішні) індивідуальні дози опромінення нащадків першого покоління мешканців РЗТ України за роками народження

\begin{tabular}{|c|c|c|c|}
\hline \multirow{2}{*}{$\begin{array}{c}\text { Досліджувані групи нащадків } \\
\text { першого покоління, } \\
\text { дати народження }\end{array}$} & \multicolumn{3}{|c|}{$\begin{array}{c}\text { Середні дози сумарного } \\
\text { опромінення нащадків за статтю, } \\
\text { мЗв }(\mathrm{M} \pm)\end{array}$} \\
\hline & чоловічої & жіночої & разом \\
\hline Перша, 01.03.1987-28.02.1990 & $2,02 \pm 1,54$ & $1,99 \pm 1,46$ & $2,00 \pm 1,50$ \\
\hline Друга, 01.03.1990-28.02.1993 & $2,29 \pm 1,64$ & $2,26 \pm 1,66$ & $2,27 \pm 1,65$ \\
\hline Третя, 01.03.1993-29.02.1996 & $2,03 \pm 1,28$ & $2,03 \pm 1,31$ & $2,03 \pm 1,29$ \\
\hline Четверта, 01.03.1996-28.02.1998 & $1,77 \pm 1,10$ & $1,69 \pm 1,00$ & $1,73 \pm 1,05$ \\
\hline
\end{tabular}

(100\%), з них $50615(62,5 \%)-$ чоловіки, $491117(37,5 \%)-$ жінки. Вік батьків при народженні дітей - нащадків першого покоління був від 18 до 49 років, 3 них 66\% батьків віком від 18 до 34 років.

Для вивчення структури непухлинної захворюваності було сформовано базову когорту нащадків першого покоління віком до 18-ти років з числа мешканців РЗТ 3 визначеними індивідуальними дозами іонізуючого опромінення у 8-ми районах 4-х областей України, а саме: Київської, Житомирської, Рівненської та Чернігівської [9, 10]. Базова когорта налічує 15174 (100\%) осіб, з них нащадків чоловічої статі 7681 (50,62\%), жіночої - 7493 $(49,38 \%)$. 3 урахуванням вікової періодизації Квінна [11] дітей розподілено на 4 досліджувані групи віком 0-3 роки (табл. 1) .

Сумарні (зовнішні та внутрішні) індивідуальні дози опромінення нащадків першого покоління мешканців РЗТ України, які були реконструйовані науковцями - дозиметристами Національного наукового центру радіаційної медицини Національної академії медичних наук України за 19872012 роки, подано у таблиці 2 $[9,10]$.

Епідеміологічне спостереження нащадків проводилося від народження до досягнення ними 18-річчя. Період спостереження першої досліджуваної групи був з 1987 по 2007 р., другої - з 1990 по 2011 р., третьої - з 1993 по 2013 р., четвертої - з 1996 по 2017p.

За період епідеміологічного спостереження (1987-2017) оцінювали особливість прояву вперше виявлених непухлинних захворювань за одним 3 трьох показників математичних параметрів, а саме: за відсотковим співвідношенням частки до цілого у структурі захворювань. Кількість усіх вперше виявлених непухлинних хвороб прийнято за 100\% у кожній статево-віковій досліджуваній групі.

Структура вперше виявлених непухлинних захворювань вивчалася за вісьмома класами MKX-X: хворобами ендо- 
кринної системи, розладами харчування та порушеннями обміну речовин (Е00-E90), розладами психіки та поведінки (F00-F99), хворобами нервової системи (G00-G99), органів дихання (J00-J99), травлення (К00-К93), системи кровообігу (І00-І99), кістковом'язової системи та сполучної тканини (М00-М99), вродженими аномаліями, вадами розвитку (Q00-Q99), симптомами, ознаками та відхиленнями від норми, виявленими клінічними та лабораторними дослідженнями, не класифікованих в інших рубриках (R00R99).

Показник (\%) структури непухлинних захворювань розраховувався за формулою:

$\mathrm{C}=\mathrm{n} \times 100 / \mathrm{N}$,

де C - структура, n - чисельність вперше виявлених хвороб за певним класом у досліджуваній групі, N загальна чисельність вперше виявлених хвороб у досліджуваній групі.

Розрахунок показників проводився з використанням програми «Microsoft Office Excel2013» [12].

Результати дослідження. Вивчення структури непухлинних захворювань нащадків першого покоління мешканців радіаційно-забруднених територій з визначеними сумарними дозами опромінення протягом 18 років їхнього життя показало, що вперше виявлено 18797 (100\%) випадків непухлинних захворювань під час щорічних медичних диспансерних оглядів, 3 них у чоловіків - 9185 $(48,86 \%)$, у жінок - 9612 (51,14\%).

Встановлено, що основними складовими у структурі непухлинних захворювань нащадків першого покоління мешканців РЗТ загальної когорти (I-IV досліджуваних груп) є хвороби органів дихання (J00-J99), органів травлення (К00-К93) та хвороби ендокринної системи, розладу харчування та порушення обміну речовин (E00-E90). Разом вони становлять 74,29\% (рис. 1).

Значні частки у структурі загальної когорти значаться за хворобами кістково-м'язової системи та сполучної тканини, системи кровообігу, органів

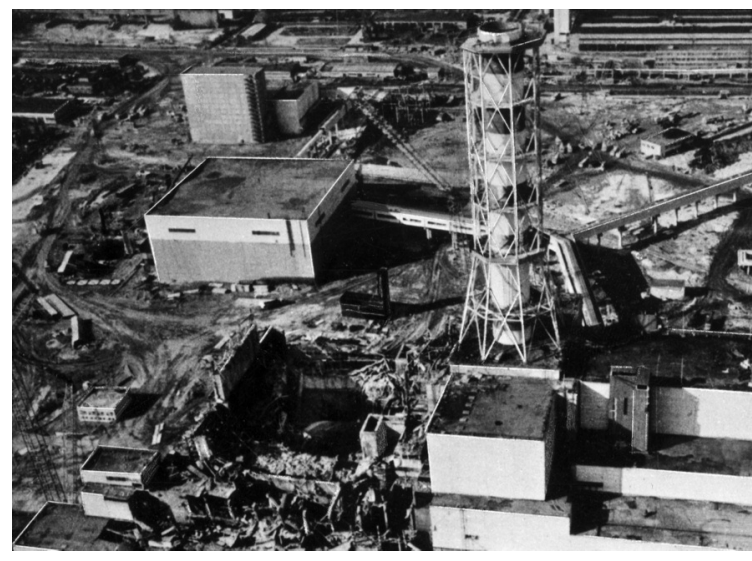

ПРОБЛЕМИ ЧОРНОБИЛЯ

нервової системи (6-7\%).

Структуру вперше виявлених непухлинних захворювань нащадків першого покоління залежно від статі надано у таблиці 3.

Структура захворювань чоловіків і жінок відображає структуру хвороб загальної когорти. Так, хвороби органів дихання, травлення, ендокринної системи у нащадків посідають 1-3 місця відповідно незалежно від статі. Також зберігаються значні частки за хворобами кістково-м'язової системи та сполучної тканини, системи кровообігу, органів нервової системи. При цьому у відсотковому співвідношенні у чоловіків превалюють хвороби органів дихання (майже на

Структура вперше виявлених непухлинних захворювань нащадків першого покоління загальної когорти мешканців радіаційно-забруднених територій за 18-річний період спостереження, \%

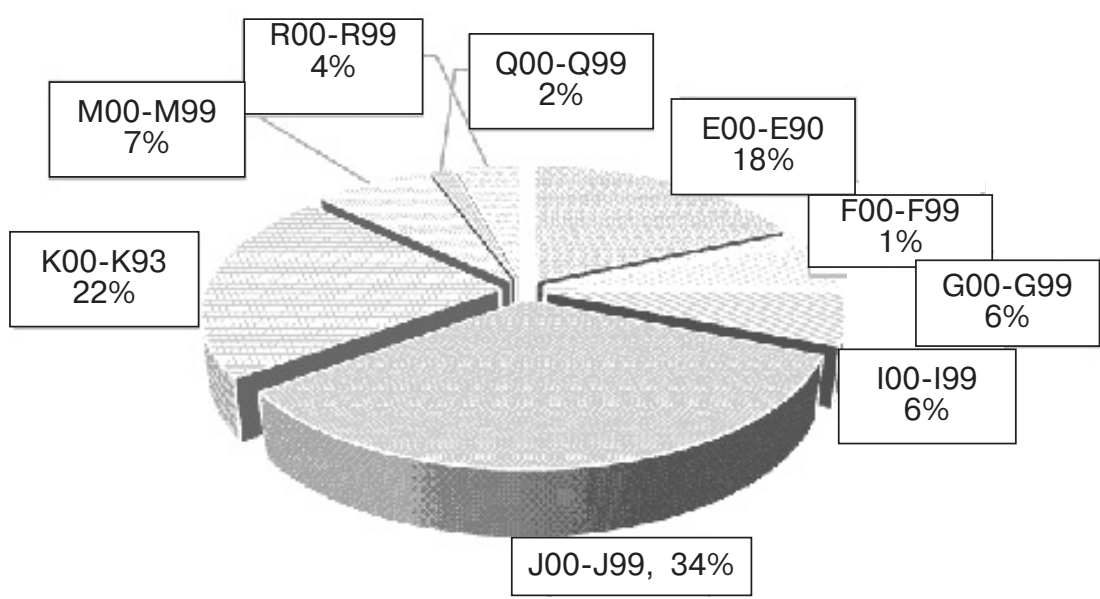

Примітки:

EOO-E90 - хвороби ендокринної системи, розладу харчування та порушення обміну; FOO-F99 - розлади психіки та поведінки;

G00-G99 - хвороби нервової системи;

100-199 - хвороби системи кровообігу;

\section{Рисунок 1}

4\%), а у жінок - хвороби ендокринної системи, розладу харчування та порушення обміну речовин (майже на 2\%), хвороби органів травлення (майже на 5\%).

Встановлено особливість у структурі вперше виявлених непухлинних хвороб нащадків першого покоління залежно років їх народження після аварії. У кожній з чотирьох груп основними частками у структурі захворювань є хвороби органів дихання, травта ендокринної системи. За хворобами органів дихання: у I досліджуваній групі - 24,76\%, у II - 36,34\%, у III - 43,08\%, y IV - 45,88\%. 3a хворобами органів травлення відповідно: 26,93\%, 21,72\%,
Ј00-J99 - хвороби органів дихання;

К00-К9З - хвороби органів травлення;

М00-М99 - хвороби кістковом'язової системи;

Q00-Q99 - вроджені аномалії, вади розвитку;

ROO-R99 - симптоми, ознаки та відхилення від норми. 
$17,74 \%, 9,66 \%$. За хворобами ендокринної системи відповідно: $22,3 \%, \quad 16,51 \%$, $14,66 \%, \quad 15,82 \%$. Значні частки мають хвороби кістково-м'язової системи та сполучної тканини, нервової системи та системи кровообігу. За хворобами кістковом'язової системи та сполучної тканини: $7,72 \%, 7,46 \%$, 6,82\%, 7,09\% відповідно у кожній групі. За хворобами нервової системи: 5,97\%, 5,73\%, 4,31\%, 6,8\%. За хворобами системи кровообігу: 5,39\%, 6,34\%, 6,05\%, 6,94\%.

Залежно від часу народження нащадків після аварії на ЧАЕС прослідковується різновекторність змін показника вперше виявлених непухлинних захворювань у структурі кожної 3 досліджуваних груп за період спостереження.

Так, за хворобами органів дихання відбулося поступове збільшення відсотків з I до IV групи майже вдвічі (на $21,12 \%)$. У чоловіків та жінок цей показник відображає зміни у досліджуваних групах загалом. Частка хвороб за класом вроджені аномалії, вади розвитку у дітей, народжених за 10-12 років після аварії на ЧАЕС, вдвічі більша порівняно 3 народженими у перші роки. Такі зміни сталися за рахунок збільшення показника у жінок, у чоловіків - зростання частки вроджених аномалій, вад розвитку не спостерігалося. За класом хворо- би органів травлення - протилежний напрямок змін показника, тобто поступове зменшення від I до IV досліджуваної групи на 17,27\% (майже втричі). Зміна цього показника за статтю відображає структуру досліджуваних груп. Захворювання за хворобами ендокринної системи та розладами психіки і поведінки у дітей, народжених у перші роки після аварії, незначно перевищують показник порівняно з іншими досліджуваними групами.

За даними класами серед чоловіків і жінок спостерігалася така ж залежність змін показника, як і у досліджуваних групах загалом. За класами хвороби кістково-м'язової системи та сполучної тканини, нервової системи, системи кровообігу, симптоми, ознаки та відхилення від норми значних змін показника серед досліджуваних груп не відбулося.

Вперше виявлено непухлинні захворювання, за якими вивчався стан здоров'я нащадків першого покоління, народжених після аварії на ЧAEC, формуються за рахунок наступних груп та нозологій. Переважну більшість у класі хвороби органів травлення становлять хвороби жовчного міхура, жовчовивідних шляхів та підшлункової залози, хвороби стравоходу, шлунка та 12-палої кишки, гастрит та дуоденіт. у класі хвороби органів дихання основними за відсотками $€$ гострі респіраторні інфекції верхніх дихальних шляхів, грип та пневмонія, інші гострі респіраторні інфекції нижніх дихальних шляхів (гострий бронхіт), інші хвороби верхніх дихальних шляхів.

Серед хвороб ендокринної системи, розладу харчування та порушення обміну найбільша частка - за хворобами щитоподібної залози, які пов'язані з йодною недостатністю, іншими формами нетоксичного зобу та тиреотоксикозом.

Найбільші відсотки у класі розлади психіки та поведінки посідають розумова відсталість та розлади, пов'язані з психологічним розвитком та настроєм.

Розлади вегетативної нервової системи мають найбільші відсотки серед хвороб нервової системи.

Серед хвороб системи кровообігу найбільшу частку становить кардіоміопатія. Хвороби кістково-м'язової системи та сполучної тканини формуються за рахунок деформуючих дорсопатій.

Питома вага у класі вроджені аномалії, вади розвитку належить вродженим вадам розвитку системи кровообігу, сечової системи, вродженим вадам розвитку та деформації кістково-м'язової системи Найбільші відсотки - за симптомами та ознаками, що нале-

\section{Структура вперше виявленої непухлинних захворювань чоловіків і жінок загальної когорти за 18-річний період спостереження}

\begin{tabular}{|l|c|c|c|}
\hline \multicolumn{1}{|c|}{ Класи хвороб за МКX-X } & \multirow{2}{*}{$\begin{array}{c}\text { Шифр } \\
\text { за MKX-X }\end{array}$} & \multicolumn{2}{c|}{ Вперше виявлені захворювання, \% } \\
\cline { 3 - 4 } & Чоловіки & Жінки \\
\hline Усі хвороби & E00-R99 & 100 & 100 \\
\hline $\begin{array}{l}\text { Хвороби ендокринної системи, розладу } \\
\text { харчування та порушення обміну речовин }\end{array}$ & E00-E90 & 17,32 & 0,79 \\
\hline Розлади психіки та поведінки & F00-F99 & 1,43 & 6,32 \\
\hline Хвороби нервової системи & G00-G99 & 4,89 & 5,74 \\
\hline Хвороби системи кровообігу & I00-I99 & 6,18 & 31,94 \\
\hline Хвороби органів дихання & J00-J99 & 35,91 & 24,46 \\
\hline Хвороби органів травлення & K00-K93 & 19,55 & 6,47 \\
\hline $\begin{array}{l}\text { Хвороби кістково-м'язовї системи } \\
\text { та сполучної тканини }\end{array}$ & M00-M99 & 8,38 & 1,18 \\
\hline Вроджені аномалії, вади розвитку & Q00-Q99 & 1,67 & 3,78 \\
\hline $\begin{array}{l}\text { Симптоми, ознаки та відхилення від норми, } \\
\text { виявлені при клінічних та лабораторних } \\
\text { дослідженнях, не класифіковані в інших рубриках }\end{array}$ & R00-R99 & 4,58 & \\
\hline
\end{tabular}


THE HEALTH OF THE CHILDREN - RESIDENTS OF RADIATION-CONTAMINATED TERRITORIES, BORN AFTER THE CHORNOBYL DISASTER Yaroshenko Zh.S.

State Institution «National Research Center for Radiation Medicine, National Academy of Medical Sciences of Ukraine», Kyiv, Ukraine

Objective: We studied the structure of non-neoplastic diseases of the descendants of the first generation, the residents of the of radiation-contaminated territories, born in 1987-1999.

Materials and methods: The database of the State Register of Ukraine (SRU) of the suffered from the ionizing radiation as a result of the accident at the Chornobyl NPP was a source of information. The base cohort made up 15174 descendants (7681 males, 7493 females). Depending on the date of birth after the accident, four groups with the age interval of 0-3 years old were formed: the first group was from 03.03.1987 to 28.02.1990, the second group - from 01.03.1990 to 02.28.1993, the third group - from 01.03.1993 to 28.02.1996, the fourth one - from 03.01.1996 to 02.28.1999. The period of epidemiological study constituted 18 years from the date of birth of the descendants. We studied the structure of non-neoplastic diseases. The parameter was calculated with the help of the Microsoft Office Excel 2013 software package.

Results: First, as a result of the epidemiological study, the features of changes in the structure of non-neoplastic diseases in the descendants of the first generation, depending on the date of birth after the accident, are shown. The diseases of the respiratory, digestive, and endocrine systems played the main role in the change of the structure and accounted for the majority of all diseases (75\%). At the same time, diseases of the respiratory organs prevail in the boys, endocrine pathology and diseases of digestive organs prevail in the girls. The dependence of the development of non-neoplastic diseases on the time of the accident at the Chornobyl NPP and the date of birth of the descendants was revealed. The proportion of respiratory diseases, mental and behaviour disorders, as well as congenital anomalies and malformations doubled in the children born in 10-12 years after the accident in comparison with the children born in the first years after the accident.

At the same time, there is a decrease in the proportion of the diseases of the endocrine and digestive systems, depending on the years of birth of the children after the Chornobyl disaster.

Conclusions: The dependence of the development of non-neoplastic diseases by the studied classes of diseases on the time of birth after the accident at the Chornobyl NPP was revealed in the descendants of the first generation of the residents of radiation-contaminated areas.

The results of the epidemiological analysis are preliminary and require the further deep research.

\section{Keywords: the descendants of the first generation, radiation-contaminated territory, non-neoplastic diseases, date of birth after the Chornobyl disaster.}

жать до систем кровообігу і дихання.

Таким чином, епідеміологічний аналіз показника структури вперше виявлених непухлинних захворювань за визначеними 8 класами у нащадків першого покоління, народжених батьками - мешканцями РЗТ, за період досягнення ними 18-річчя показав, що втрата здоров'я відбулася переважно за рахунок розвитку хвороб органів дихання $(33,88 \%)$, органів травлення $(22,06 \%)$ та ендокринної патології $(18,35 \%)$, які разом становлять 2/3 від усіх захворювань $(74,5 \%)$. Структура захворювань у чоловіків і жінок відображає структуру когорти загалом. При цьому відзначається невелика різниця за хворобами органів дихання, які превалюють у чоловіків, та за хворобами ендокринної системи і хворобами органів травлення, які переважають у жінок.

Особливістю змін показника структури захворювань серед досліджуваних груп нащадків першого покоління $€$ залежність від часу народження дітей після аварії. Так, структу- ра захворювань дітей, народжених у перші роки після аварії, значно відрізняється за співвідношенням хвороб у дітей, народжених за 10-12 років. Зазначимо, що у нащадків першої досліджуваної групи у структурі превалюють хвороби органів дихання, травлення та ендокринної системи, частка яких стано-

вить близько 22-27\%. Ці ж захворювання посідають перші місця у нащадків інших досліджуваних груп, але ми бачимо різноспрямованість змін вектора показника. У дітей, які народилися за 7-9 та 10-12 років після аварії, частка захворювань органів дихання зростає майже на 20\%, при цьому складова хвороб систе-

Рисунок 2

Структура вперше виявлених непухлинних захворювань у нащадків першого покоління залежно від років народження після аварії на ЧАЕС

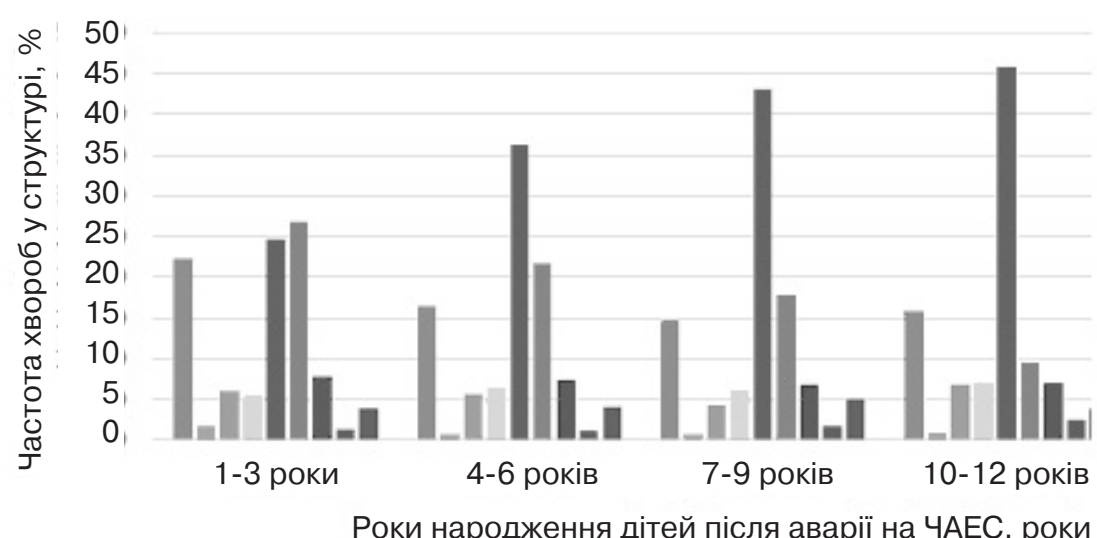

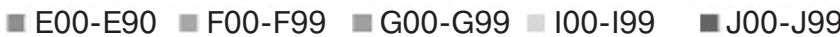

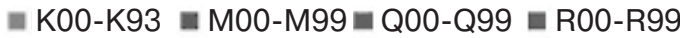


4. За хворобами органів дихання, розладами психіки та поведінки, вродженими аномаліями та вадами розвитку спостерігається поступове збільшення - майже вдвічі, частки хвороб у структурі захворювань серед нащадків, які народилися за 10-12 років після аварії, порівняно з дітьми, народженими у перші роки після катастрофи.

5. За хворобами органів ми органів травлення та ендокринної системи зменшується на $10-15 \%$ та 7\% відповідно. Також треба зауважити, що майже вдвічі збільшилася частка вроджених аномалій та вад розвитку у нащадків IV досліджуваної групи порівняно з I, хоча у загальній структурі групи дітей, які народилися за 10-12 років після аварії, вони становлять не більше 2,58\%. Цікаво, що у дітей, народжених у перші роки після аварії, відсоток розладів психіки та поведінки становить $1,67 \%$ у структурі захворювань цієї групи, але він вдвічі більший порівняно $з$ величиною показника за цим класом у дітей IV групи.

Не встановлено залежності змін показника структури за класами хвороби кістковом'язової системи та сполучної тканини, нервової системи, системи кровообігу, симптоми, ознаки та відхилення від норми, від часу народження дітей після аварії на ЧАЕС.

\section{Висновки}

1. 3 досягненням 18-річчя у нащадків першого покоління, народжених з 1987 по1999 рік батьками - мешканцями РЗТ, втрата здоров'я відбулася переважно за рахунок розвитку захворювань органів дихання, травлення та патології ендокринної системи, які становлять разом близько $75 \%$ у структурі.

2. Серед нащадків чоловічої статі превалюють хвороби органів дихання, а в осіб жіночої статі - хвороби ендокринної системи, розлади харчування і порушення обміну речовин та хвороби органів травлення.

3. Встановлено залежність розвитку непухлинних захворювань від часу аварії на ЧАЕС та дати народження нащадків. травлення та ендокринної системи спостерігається зменшення частки у структурі захворювань дітей, III та IV досліджуваних груп.

Отримані результати епідеміологічного дослідження структури вперше виявлених непухлинних захворювань нащадків (перше покоління) мешканців радіаційно-забруднених територій з визначеними дозами сумарно-іонізуючого опромінення протягом 18 років життя $є$ попередніми та потребують подальших досліджень.

ЛІТЕРАТУРА

1. Про правовий режим території, що зазнала радіоактивного забруднення внаслідок Чорнобильської катастрофи : Закон України № 791а-XII. Київ, 1991. Ст. 2. URL : https://zakon.rada. gov.ua/laws/show/791a-12

2. Бебешко В.Г., Прістер Б.С., Омельянець М.І. Радіо-біофізичні та медикогігієнічні наслідки Чорнобильської катастрофи: шляхи пізнання та подолання. Практичний посібник сімейного лікаря. Ужгород : Патент, 2017. 502 р.

3. Базика Д.А., Іллєнко І.М., Музалевська К.Д.,

Бєляєва Н.В. Імунологічні ефекти. Тридцять років Чорнобильської катастрофи: радіологічні та медичні наслідки : Національна доповідь України / Базика Д.А., Тронько М.Д., Антипкін Ю.Г. Сердюк А.М., Сушко В.О. (ред.). Київ, 2016. С. 92-94. URL : https://drive. google.com/file/d/OB1bUIW1Y ACgZUWIVW2ktbmNKTjg/view

4. Бузунов В.О., Прикащикова К.Є., Костюк Г.В. Марценюк О.Д., Губіна І.Г. Непухлинна захворюваність мешканців радіоактивно- забруднених територій України. Тридцять років Чорнобильської катастрофи: радіологічні та медичні наслідки : Національна доповідь України / Базика Д.А., Тронько М.Д., Антипкін Ю.Г. Сердюк А.М., Сушко В.О. (ред.). Київ, 2016. С. 51-62. URL : https://drive.google. com/file/d/OB 1bUIW1YACgZU WIVV2ktbmNKTjg/view

5. Державна служба статистики України. Заклади охорони здоров'я та захворюваність населення України у 2017 році. Статистичний збірник. Київ, 2018. 109 р.

6. Степанова Е.И., Вдовенко В.Ю. Кондрашова В.Г. Колпаков И.Е. Чернобыльская катастрофа и здоровье детей. Новая медицина тысячелетия. 2010. № 4. 18-22.

7. Півень Н.В., Гунько Н.В., Короткова Н.В.

Захворюваність дитячого населення найбільш радіоактивно-забруднених територій України хворобами органів травлення. Довкілля та здоров'я. 2014. № 4. С. 55-60.

8. Степанова Е.И. Скварская О.С. Роль полиморфизма генов NO-синтаз в патогенезе мультифакториальных заболеваний.

Лікарська справа. 2014 ; 5-6 : 47-55 (in Russian).

9. Лихтарев И.А., Ковган Л.Н., Масюк С.В. Иванова О.Н., Чепурной Н.И., Бойко З.Н. и др.

Реконструкции индивидуальных доз внутреннего облучения для лиц Украины в Госреестре: доклад 1. Локальные специфические модели и дозы облучения лиц, проживающих в Рокитновском районе Ровенской области, Овручском районе Житомирской области, Иванковском районе Киевской области. Проблемы радиационной медицины и радиобиологии. 2014.

Вып. 19. С. 80-101. URL:

http://radiationproblems.org.ua /ukr prmr 201419 7.html

10. Лихтарев И.А., Ковган Л.Н., Масюк С.В., Иванова О.Н., Чепурной Н.И., Бойко З.Н. и др.

Реконструкции индивидуаль- 
ных доз внутреннего облучения лиц Украины в Госреестре: доклад 2.

Локальные специфические модели и дозы облучения лиц, проживающих в

Козелецком и Репкинском районах Черниговской области. Проблемы радиационной медицины и радиобиологии. 2014. Вып. 19. С. 102-125. URL :http://radiationproblems. org.ua/ukr_prmr_2014_19_8.html

11. QuinnV.N. Applying

Psychology. McGraw-Hill Inc., US, 1989.

12. Бузунов В.О., Пирогова О.Я., Краснікова Л.І., Цуприков В.А., Войчулене Ю.С., Домашевська Т.Є. Показники та методи їх розрахунку в епідеміології неінфекційних захворювань. Навчально-методичний посібник. Київ : Авіценна, 2013. $120 \mathrm{p}$.

\section{REFERENCES}

1. Pro pravovyi rezhym terytorii, shcho zaznala radioaktyvnoho zabrudnennia vnaslidok Chornobylskoi katastrofy: Zakon Ukrainy № 791a-XII. Kyiv ; 1991. Art. 2 [On the Legal Regime of the Territory Exposed to Radioactive Contamination as a Result of the Chornobyl Disaster. Low of Ukraine № 791a-XII]. URL :

https://zakon.

rada.gov.ua/laws/show/791a12 (in Ukrainian).

2. Bebeshko V.H., Prister B.S. and Omelianets M.I. Radiobiofizychni ta medykohihienichni naslidky Chornobylskoi katastrofy: shchliakhy piznannia ta podolannia. Praktychnyi posibnyk simeinoho likaria [Radio-Biophysical and Medico-Hygienic Consequences of the Chornobyl Disaster: Ways of Knowledge and Overcoming. Practical Manual for Family Doctor]. Uzhhorod : Patent ; 2017 : 502 p. (in Ukrainian).

3. Bazyka D.A., Ilenko I.M., Muzalevska K.D. and Beliaieva N.V. [Immunological Effects]. In : Bazyka D.A., Tronko M.D., Antypkin Yu.H., Serdiuk A.M. and Sushko V.O. (Eds.). Trydtsiat rokiv Chornoblskoi katastrofy : radiolohichni ta medychni naslidky: atsionalna dopovid Ukrainy [Thirty Years of the Chornobyl Disaster:
Radiological and Medical Consequences: National Report of Ukraine]. Kyiv ; 2016 : 92-94. URL : https://drive.google. com/file/d/OB1bUIW1YACgZU WIVV2ktbmNKTjg/view

(in Ukrainian).

4. Buzunov V.O.,

Prykashchykova K.Ye., Kostiuk H.V., Martseniuk O.D. and Hubina I.H. Nepukhlynna zakhvoriuvanist meshkantsiv radioaktyvno zabrudnenykh terytorii Ukrainy [Non-

Neoplastic Morbidity of the Inhabitants of RadiationContaminated Territories of Ukraine]. In : Bazyka D.A. Tronko M.D., Antypkin Yu.H., Serdiuk A.M. and Sushko V.O. (Eds.). Trydtsiat rokiv Chornoblskoi katastrofy: radiolohichni ta medychni naslidky: Natsionalna dopovid Ukrainy [Thirty years of the Chornobyl Disaster: Radiological and Medical Consequences: National Report of Ukraine]. Kyiv ; 2016 : 51-62. URL :

https://drive.google.com/file/d /OB1bUIW1YACgZUWIVV2ktbm NKTjg/view (in Ukrainian).

5. Derzhavna sluzhba statystyky Ukrainy. Zaklady okhorony zdorovia ta zakhvoriuvanist naselennia Ukrainy. Statystychnyi zbirnyk [State Statistics Service of Ukraine. Healthcare Institutions and Morbidity of the Population of Ukraine in 2017. Statistical Collected Book]. Kyiv; 2018 : 109 p. (in Ukrainian).

6. Stepanova E.I.,

Vdovenko V.Yu.

Kondrashova V.H. and

Kolpakov I.E. Chernobylskaya

katastrofa i zdorovie detei [The Chornobyl disaster and the health of the children]. Novaya meditsina tysiacheletiia. 2010 ; 4 : 18-22 (in Russian).

7. Piven N.V., Hunko N.V. and Korotkova N.V. Dovkillia ta zdorovia. 2014 ; 4 : 55-60 (in Ukrainian).

8. Stepanova E.I. and Skvarska O.S. Likarska sprava. 2014 ; 5-6 : 47-55 (in Russian).

9. Likhtariov I.A., Kovhan L.N., Masiuk S.V., Ivanova O.N., Chepurnoy N.I., Boiko Z.N. et al. Rekonstruktsiya individualnykh doz vnutrennego oblucheniya dlya lits Ukrainy v Gosreestre: doklad 1. Lokalnye spetsificheskie modeli i dozy oblucheniya lits,

prozhivayushchikh v Rokitnovskom rayone

Chernigivskoy oblasti, Ovruch-

skom rayone Rovenskoy oblasti, Ivankovskom rayone Kievskoy oblasti Reconstruction of the Individual Doses of Internal Irradiation for the People of Ukraine in the State Register:

Report 1. Local Specific Models and Doses of Irradiation of the People Residing in the Rokitnivskyi Region, Rivne Oblast; Ovruchskyi Region, Zhytomyr Oblast; Ivankivskyi Region, Kyiv Oblast]. In : Problems of Radiation Medicine and Radiobiology. $2014 ; 19$ : 80-101. URL: http://radiationproblems.org.ua/ukr_prmr_201 4_19_7.html (in Russian).

10. Likhtariov I.A., Kovhan L.N., Masiuk S.V., Ivanova O.N., Chepurnoy N.I. Boiko Z.N. et al. Rekonstruktsiya individualnykh doz vnutrennego oblucheniya dlya lits Ukrainy v Gosreestre: doklad 2. Lokalnye spetsificheskie modeli i dozy oblucheniya lits, prozhivayushchikh v Kozeletskom i Repkinskom rayonakh Chernigivskoy oblasti [Reconstruction of the Individual Doses of Internal Irradiation for the People of Ukraine in the State Register:

Report 2. Local Specific Models and Doses of Irradiation of the People Residing in Kozeletskyi and Ripkivskyi Distrikts, Chernigiv Region]. Problems of Radiation Medicine and Radiobiology. 2014 ; 19 : 102125. URL : http://radiationproblems.org.ua/ukr prmr 2014 19 _8.html (in Russian).

11. QuinnV.N. Applying Psychology. McGraw-Hill Inc., US, 1989.

12. Buzunov V.O.

Pyrohova O.Ya., Krasnikova L.I., Tsuprykov V.A., Voichulene Yu.S. and Domashevska T.Ye.

Pokaznyky ta metody yikh rozrakhunku v epidemiolohii neinfektsiinykh zakhvoriuvan. Navchalno-metodychnyi posibnyk. [Parameters and Methods for their Calculation in the Epidemiology of Non-infectious Diseases.

Educational-and-Methodical Manual]. Kyiv : Avitsena ; 2013: 120 p. (in Ukrainian).

Надійшла до редакції 14.05.2019 